\title{
Sucralose induced pancreatic toxicity in albino rats: Histomorphological evidence
}

\author{
GUPTA, S. ${ }^{1}$, KALRA, S. ${ }^{2 *}$, BHARIHOKE, $^{3}{ }^{3}$ and DHURANDHAR, D. ${ }^{4}$ \\ ${ }^{1}$ University College of Medical Sciences, Delhi- 110095, India \\ ${ }^{2}$ Associate Professor, Department of Anatomy, University College of Medical Sciences, Delhi-110095, India \\ ${ }^{3}$ Ex Head and Professor, Department of Anatomy, University College of Medical Sciences, Delhi-110095, India \\ ${ }^{4}$ Resident Doctor, Department of Anatomy, University College of Medical Sciences, Delhi-110095, India \\ *E-mail: net3laug@yahoo.co.in
}

\begin{abstract}
In the present world people have become conscious of the fact that sugar is one of the commonest culprits for gain in weight and blood sugar in diabetes. One of the artificial sweetener, sucralose is widely used by diabetics is still under strict scrutiny because of the contradictory feedbacks obtained from various studies, often discouraging its use. Therefore, there arises a need to check whether the use of sucralose is safe or not. The present study was designed to determine to evaluate and compare the histological changes of sucralose on the islets of pancreas in albino rats. Methods: The adult Wistar albino rats were given sucralose orally by gavage in the dose of $3 \mathrm{gms} / \mathrm{kg}$ body weight/day dissolved in distilled water and only distilled water for 30 days to experimental and control groups respectively. The animals were weighed prior to and after the experiment. The animals were sacrificed on day 31 . The pancreas was dissected and observed grossly. Tissue was processed; paraffin blocks were prepared and 8 micron thick sections were cut. Sections were stained with Haemotoxylin and Eosin and Gomori's stains. Results: Pancreatic toxicity was observed in the form of vaculation of islets, lymphocytic infilterate, degeneration of islets and acini of Pancreas. The commonly used non-lethal dose of sucralose induced damage to Pancreas is startling. Conclusion: The results obtained have wide implications for nutrient sensing and nutrition in the treatment of obesity and diabetes.
\end{abstract}

Keywords: diabetes, pancreas, sucralose, toxicity.

\section{Introduction}

In the present world people have become conscious of the fact that sugar is one of the commonest culprits for gain in weight and blood sugar in diabetes. The number of diabetic people has been ever increasing. In a study it has been reported that 347 million people worldwide have diabetes (DANAEI, FINUCANE, LU et al., 2011). World Health Organization - WHO (2011) projects that diabetes will be the 7th leading cause of death in 2030 . More than $80 \%$ of diabetes deaths occur in low- and middle-income countries (MATHERS and LONCAR, 2006). Diabetes as is understood is a condition characterized by hyperglycemic state either due to autoimmune response against the $\beta$ cells of pancreas or due to some genetic defect affecting carbohydrate metabolism and finally deranging the blood glucose levels. The mainstay of treatment of diabetes has been the scrupulous control of euglycemic state. With this, many diabetic patients have also resorted to using artificial sweeteners such as sucralose, aspartame etc. which are now easily available and found in products of daily consumption. As sucralose is present in more than 3000 beverages and food products, many of which are essential component in the routine diet, people are likely to consume unlimited amount of this substance (MCNIEL..., 1998). Therefore, it becomes obligatory to check whether these artificial sweeteners, mainly sucralose are safe for humans or not. Sucralose is obtained by the selective chlorination of sucrose. Till now it's been accepted that sucralose is calorie-free and is simply excreted out without being digested or being absorbed by the body, thus affecting the body minimally. Howsoever, studies involving exclusive use of sucralose over a significant duration of time have shown some severe side effects which are explainable by the knowledge that sucralose is a chlorocabon and such chlorinated compounds are the basis for pesticides such as DDT (MANN, YUSCHAK, AMYES et al., 2000). However, in a study in which the rodents were fed sucralose for 104 weeks with dose of $1500 \mathrm{mg} / \mathrm{kg} /$ day weren't found to manifest any carcinogenic or harmful effects (MANN, YUSCHAK, AMYES et al., 2000).

Pancreas has a pivotal role in carbohydrate metabolism. Developmentally pancreas gets fully developed by the 30th week of IUL, having highest density of the islets in the tail of the pancreas (GUPTA, GARG, RAHEJA et al., 2002). An islet has $\alpha$-cells, $\beta$-cells, D-cells and PP-cells, out of which, the $\beta$-cells occupy the center and constitute about $70-75 \%$ of cell population. Some studies suggest that intestinal sweet taste receptors (which can be stimulated by artificial sweeteners also) stimulate GLUT-2 receptors, and thus increase glucose absorption (MACE, AFFLECK, PATEL et al., 2007). According to another study glucose provides mitogenic stimulus to $\beta$ cells, which has been proved by monitoring immunofluorescence for insulin, and performing BrdU or TUNEL, after administering glucose in pancreatic graft recipients (LEVITT, CYPHERT, PASCOE et al., 2011). Also, sweet taste receptors found on pancreatic $\beta$ cells directly stimulate them by $\mathrm{Ca}+2$ pathway to release more insulin (NAKAGAWA, NAGASAWA, YAMADA et al., 
2009). Assuming that sucralose might affect glucose uptake or directly act on the $\beta$ cells and thus affect the $\beta$-cell mass, it becomes necessary to look for any histomorphological changes in pancreas with continued use of sucralose.

The scientific literature lags behind in providing the basic and the most reliable proof to assure for the safety of sucralose, i.e. the anatomical proof. Thus, the present study was designed to determine the effects of sucralose on the histomorphology of pancreas in albino rats, which at the anatomical level, will stand to be proof enough for the adverse effects of sucralose on pancreas, if any.

\section{Materials and Methods}

The study was conducted only after obtaining appropriate ethical clearance from the animal ethical committee. Adult Wistar albino rats twelve in number, weighing 150-200 gms were procured . The animals were divided into two groups of 6 rats each i.e., Group 1 as experimental and Group 2 served as controls.

The rats were kept in separate cages in normal lighting conditions. They were given food and water ad libitum. Group 1 rats were given sucralose orally by oral gavage in the dose of $3 \mathrm{gms} / \mathrm{kg} /$ day dissolved in distilled water for 30 days. Group 2 also received equal quantity of distilled water by the same route and for the same time duration. The animals of both the groups were sacrificed within 24 hours of the administration of the last dose and were perfused with formal saline under ether anesthesia. Whole of the pancreas was dissected out and divided into a head and a tail part. The dissected pancreas was checked for gross changes. Then, the tissue was processed, embedded in paraffin wax and 8 micron sections of both, the tail and the head parts of the pancreas were cut. These sections were stained by the Haematoxylin and eosin (H\&E) and Gomori's chrome alum haematoxylin and phyloxine stains. The stained sections were studied for histomorphological changes.

\section{Results}

All histological studies were carried out on a Radical ${ }^{\circledR}$ research microscope (RXLr-5) with a camera attached. Digital photomicrographs of the pancreatic sections were taken at various magnifications. The non-serial pancreatic histological stained sections were used for morphological analysis.

Histological assessment of the pancreas of the control group and the experimental group showed quite contrasting results. The control group depicted normal architecture of endocrine and exocrine components of the pancreas (Figure 1).

The changes observed in the experimental group included:

- Gross breakdown of micro-anatomical features including degenerative and necrotic changes, leading to wide architectural disruption (Figure 2 and 3 ).

- Few sections also showed decreased cellular density of the islets of langerhans, with vacuolations in the islet and focal lymphocytic aggregation, i.e. chronic inflammatory infiltrate in the form of lymphocytes indicating immune response against $\beta$ cells (Figure 4 and 5 ).

- Some of the sections showed significantly enlarged islets of langerhans (Figure 6).

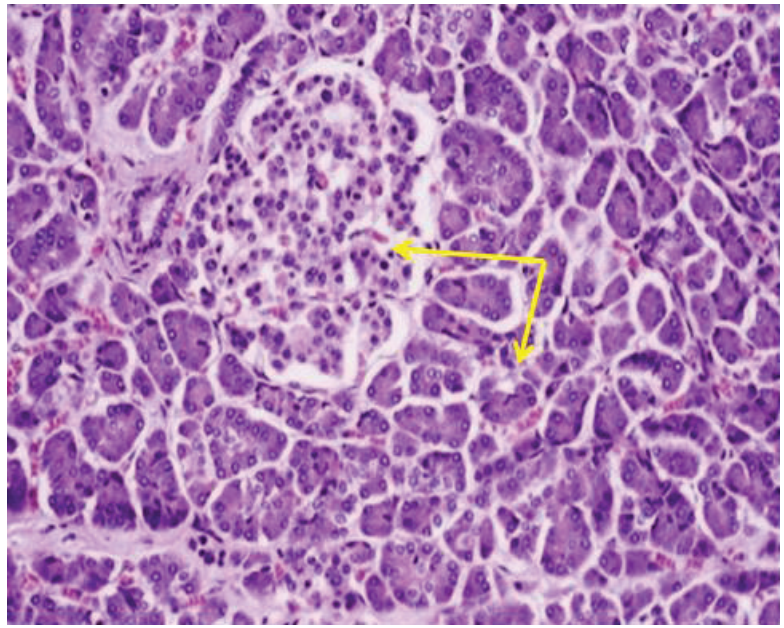

Figure 1. Photomicrograph of transverse section of Pancreas from control rat showing normal acinar and endocrine architecture of pancreas (H\&E Stain, 200X).

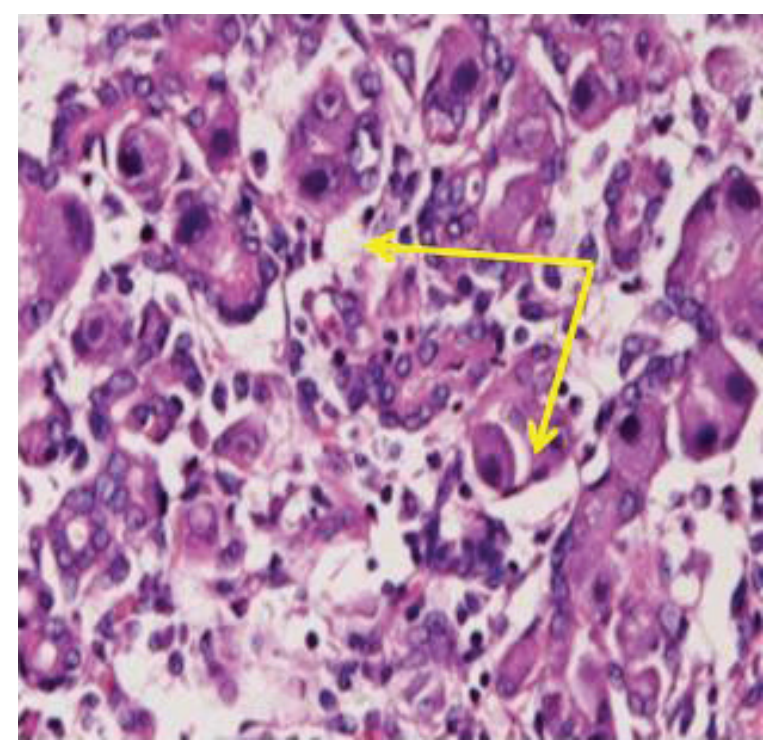

Figure 2. Photomicrograph of transverse section of Pancreas from experimental rat showing disintegration of lobular architecture of pancreas (H\&E Stain, 200X).

- Although the normal architecture was broken, the pancreatic acinar epithelium, and ductal and connective tissues appeared normal.

In the present study, almost all the slides of the experimental group showed that the islets and insulin-producing $\beta$-cells were degranulated, degenerated, or necrosed.

There was no significant change in the weight gain observed between control and experimental rats. The average weight gain in the control group in 30 days was $56.67 \pm 4.38 \mathrm{gm}$ and that of the experimental group was $60.67 \pm 3.25 \mathrm{gm}$ (p value 0.109 , insignificant $)$.

\section{Discussion}

In the present study pancreas of sucralose exposed rats showed focal lymphocytic aggregation/focal chronic infiltrate in the form of lymphocytes indicating autoimmune response 


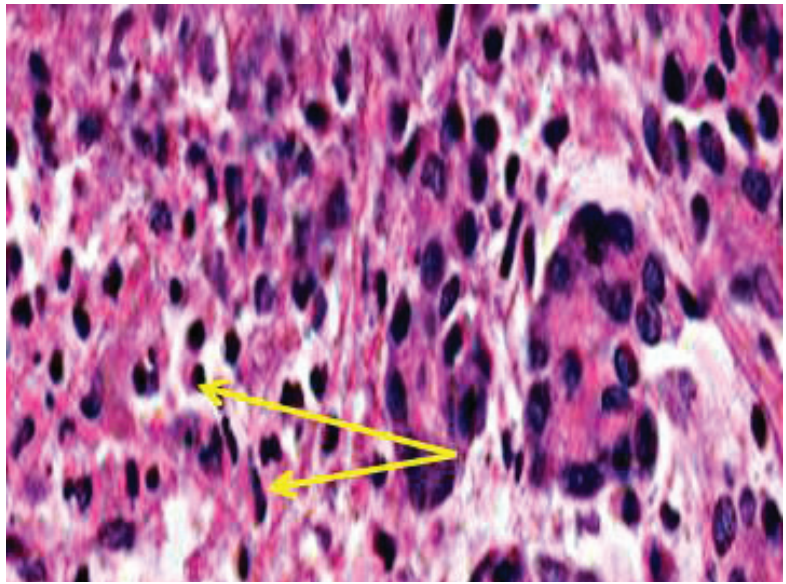

Figure 3. Photomicrograph of transverse section of pancreas from experimental rat showing degeneration of islets of langerhans (H\&E Stain, 200X).

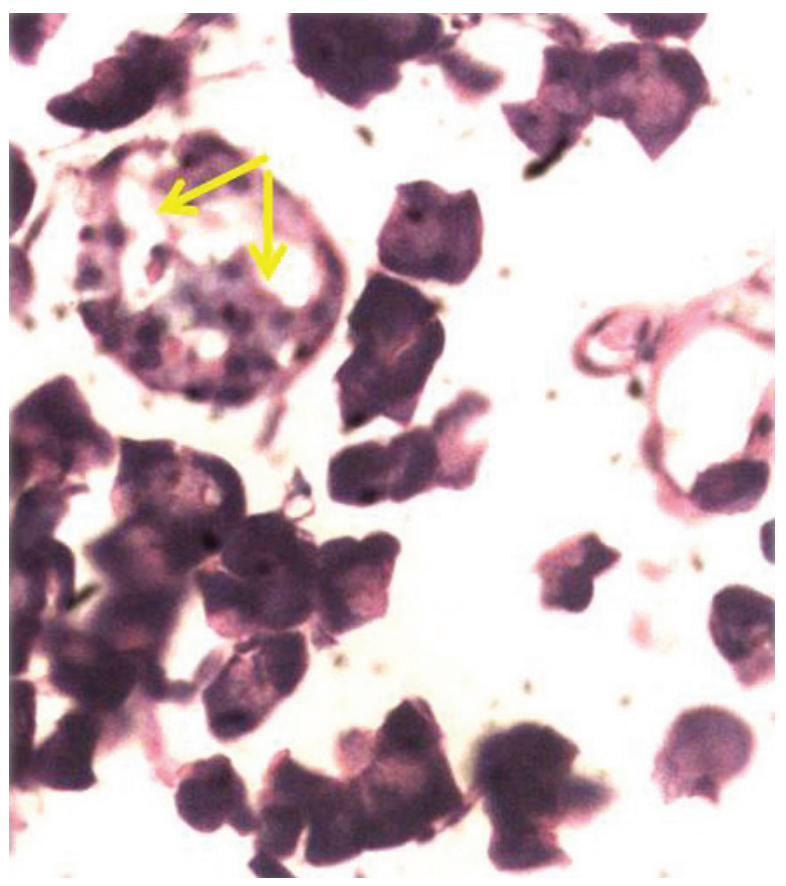

Figure 4. Photomicrograph of transverse section of pancreas from experimental rat showing vacuolation and degeneration of islets (Gomori's chrome alum haematoxylin and phyloxine stain, 200X).

against $\beta$ cells along with evidence of pancreatic toxicity in the form of vaculation of islets, degeneration of islets as well as acini of Pancreas. The histological architecture of pancreas in the sucralose exposed group was totally deranged which is in contrast with a study by Shastry, Yatheesh and Aswathanarayana (2012) which reported normal histological structure of pancreas in sucralose exposed rats comparable with controls.

In the present study sucralose has been indicated to create prediabetic state by causing $\beta$ cell destruction because of an attack by immune system in the presence of increased inflammatory response. The prediabetic phase of the disease is characterized by infiltration of islets by macrophages and $\mathrm{T}$

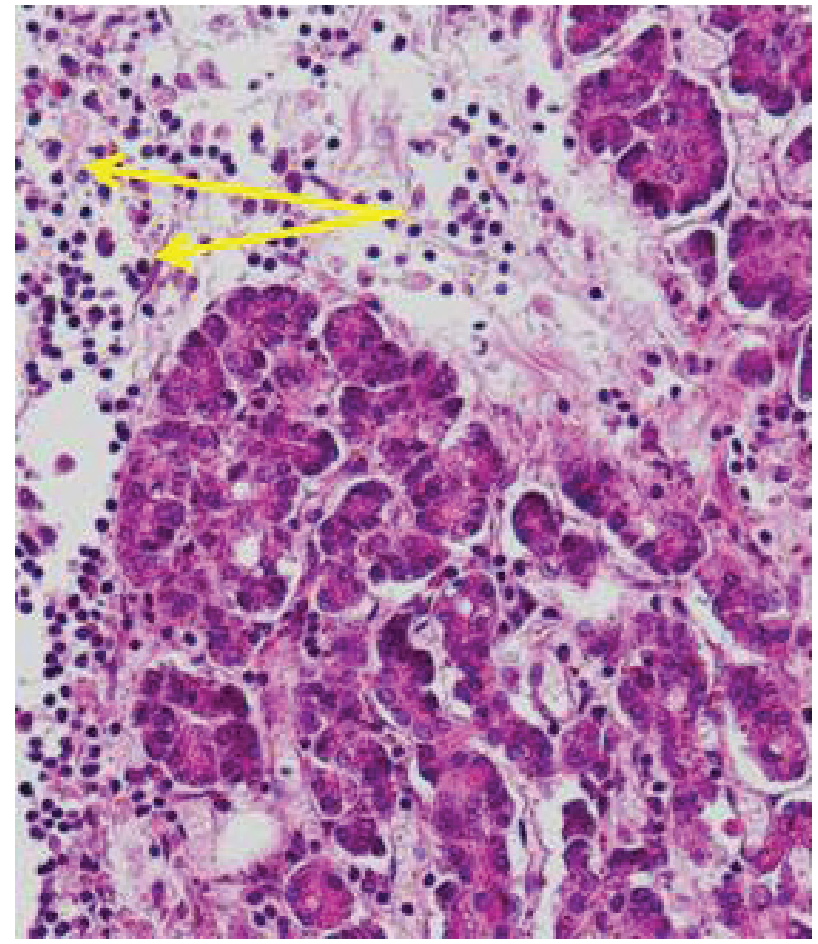

Figure 5. Photomicrograph of transverse section of Pancreas from experimental rat showing lymphocytic infiltration suggesting inflammatory response against pancreatic tissue (H\&E Stain, 200X).

cells, resulting in a scenario referred to as insulitis (TERSEY, NISHIKI, TEMPLIN et al., 2012). It has been proposed that genetic and environmental factors might account for an increased susceptibility of $\beta$ cells to both the attack by the immune system and to the dysfunction in the face of an augmented inflammatory response (ATKINSON, BLUESTONE, EISENBARTH et al., 2011). Extensive studies by Levitt, Cyphert, Pascoe et al. (2011) have also shown that the sweet taste receptors present in the gastrointestinal lining are not sufficiently stimulated by sucralose and thus it is minimally responsible for augmenting apical GLUT-2 receptor mediated glucose uptake. Thus the present study has proved the long standing hypothesis incorrect that the artificial sweeteners can lead to increased glucose uptake which can in turn increase the mitogenic stimulus to $\beta$ cells of the islet of langerhans of the pancreas. Also results in the present study were similar to the changes seen in insulitis and in diabetic mice (SHASTRY, YATHEESH and ASWATHANARAYANA, 2012; TERSEY, NISHIKI, TEMPLIN et al., 2012). But another study suggested that sucralose augments glucose mediated insulin release from the $\beta$ cell by stimulating sweet taste receptors present on the $\beta$ cells (NAKAGAWA, NAGASAWA, YAMADA et al., $2009)$. In the current study few of islets in sections prepared from experimental group were considerably enlarged. In a study by Lampert, Gurniak, Brocker et al. (1995) it was observed that subtotal pancreatectomy $(90 \%)$ in Lewis rats induced chronic islet inflammation and tissue damage in the remaining pancreas 4 months after surgery. Concomitantly, there was significant enlargement of the islets of Langerhans. 


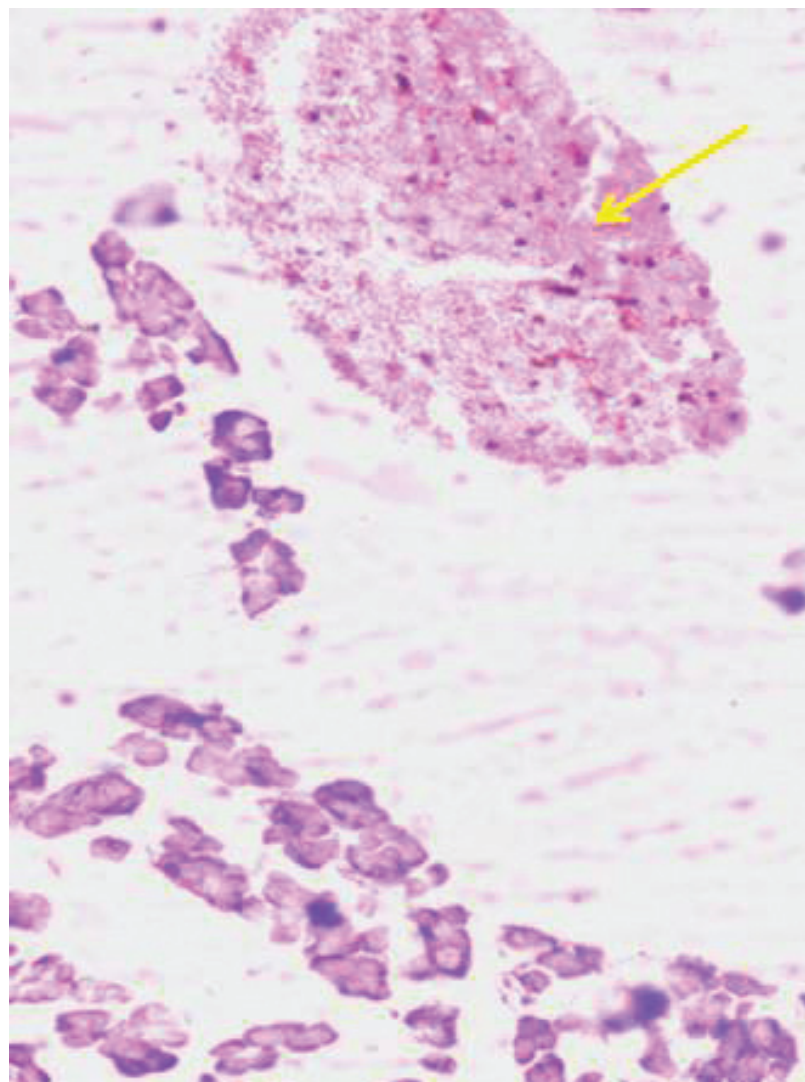

Figure 6. Photomicrograph of transverse section of Pancreas from experimental rat showing distended islets of langerhans (H\&E Stain, 100X).

It was suggested that the stimulus for growth of cells in islets could result from tissue damage caused by infiltrating cells or from cytokines secreted by the infiltrating cells, or both. This may elucidate the rationale for few of enlarged / distended islets of langerhans observed in the current study due to insultis like stage created by sucralose with exposure..

Present study revealed that sucralose ingestion causes significant damage to pancreas leading not only breakdown in architecture but widespread destruction of islets and $\beta$ cells. Also, there is no widely acknowledged value of acceptable daily intake of sucralose. Since sucralose has been found to manifest adverse effects its use as a treatment modality in diabetics as is being explored by many others still remains under scrutiny.

\section{Conclusions}

Sucralose was found to cause $\beta$ cell death exhibiting diabetogenic effect on the pancreas. After obtaining such results, the use of sucralose cannot be satisfactorily warranted to be approving for artificial sweetening and its use as a treatment approach in diabetics remains questionable and points towards the apparent gap in the knowledge. Hence, sucralose should be used with caution and over usage is not appreciated.

Acknowledgements: The present study was carried out within the framework of STS project approved by Indian Council of Medical Research, New Delhi.

\section{References}

ATKINSON, MA., BLUESTONE, JA., EISENBARTH, GS., HEBroK, M., HEROLD, KC., ACCILI, D., PIETROPAOLO, M., ARVAN, PR., HERRATH, MV., MARKEL, DS. and RHODES, CJ. How does type 1diabetes develop: the notion of homicide or b-cell suicide revisited. Diabetes, 2011, vol. 60, n. 5, p. 1370-1379. PMid:21525508 PMCid:PMC3292309.

DANAEI, G., FINUCANE, MM., LU, Y., SINGH, GM., COWAN, MJ., PACIOREK, CJ., LIN, JK., FARZADFAR, F., KHANG, YH., STEVENS, GA., RAO, M., ALI, MK., RILEY, LM., ROBINSON, CA. and EZZATI, M. National, regional, and global trends in fasting plasma glucose and diabetes prevalence since 1980: systematic analysis of health examination surveys and epidemiological studies with 370 country-years and 2.7 million participants. Lancet, 2011, vol. 378, n. 9785, p. 31-40. http://dx.doi.org/10.1016/S01406736(11)60679-X

GUPTA, V., GARG, K., RAHEJA, S., CHOUDHRY, R. and TULI, A. The histogenesis of islets in the human fetal pancreas. Journal of the Anatomical Society of India, 2002, vol. 51, n. 1, p. 23-26.

LAMPERT, EF., GURNIAK, M., BROCKER, U., KLEMENS, C., TUBES, M., FRIEMANN, J. and KOLB, H. Regeneration of betacells in response to islet inflammation. Experimental and Clinical Endocrinology \& Diabetes, 1995, vol. 103, suplemento 2, p. 74-78.

LEVITT, HE., CYPHERT, TJ., PASCOE, JL., HOLLERN, DA., ABRAHAM, N., LUNDELL, RJ., ROSA, T., ROMANO, LC., ZOU, B., O'DONNELL, CP., STEWART, AF., GARCIAOCAÑA, A. and ALONSO, LC. Glucose stimulates human beta cell replication in vivo in islets transplanted into NOD-severe combined immunodeficiency (SCID) mice. Diabetologia, 2011, vol. 54, n. 3, p. 572-582. PMid:20936253 PMCid:PMC3034833. http:// dx.doi.org/10.1007/s00125-010-1919-1

MACE, OJ., AFFLECK, J., PATEL, N. and KELLETT, GL. Sweet taste receptors in rat small intestine stimulate glucose absorption through apical GLUT2. The Journal of Physiology, 2007, vol. 582, n. 1, p. 379-392. PMid:17495045 PMCid:PMC2075289. http:// dx.doi.org/10.1113/jphysiol.2007.130906

MANN, SW., YUSCHAK, MM., AMYES, SJG., AUGHTON, P. and FINN, JP. A combined chronic toxicity/carcinogenicity study of sucralose in Sprague-Dawley rats. Food and Chemical Toxicology, 2000, vol. 38, suplemento 2, p. S71-S89.

MATHERS, CD. and LONCAR, D. Projections of global mortality and burden of disease from 2002 to 2030. PLoS Med, 2006, vol. 3 , n. 11, p. e442.

MCNEIL SPECIALTY PRODUCTS COMPANY - MSPC. Food additive petition 7A3987. Federal Register, 1998, vol. 63, n. 64, p. 16418-16449.

NAKAGAWA, Y., NAGASAWA, M., YAMADA, S., HARA, A., MOGAMI, H., NIKOLAEV, VO., LOHSE, MJ., SHIGEMURA, N., NINOMIYA, Y. and KOJIMA, I. Sweet taste receptor expressed in pancreatic beta-cells activates the calcium and cyclic AMP signaling systems and stimulates insulin secretion. PLoS One, 2009, 
vol. 4, n. 4, p. e5106. PMid:19352508 PMCid:PMC2663034. http://dx.doi.org/10.1371/journal.pone.0005106

SHASTRY, CS., YATHEESH, CK. and ASWATHANARAYANA, BJ. Comparative evaluation of diabetogenic and mutagenic potential of artificial sweeteners: aspartame, acesulfame- $k$ and sucralose. Nitte University Journal of Health Science, 2012, vol. 2, n. 3, p. 22497110.

TERSEY, SA., NISHIKI, Y., TEMPLIN, AT., CABRERA, SM., STULL, ND., COLVIN, SC., MOLINA, CE., RICKUS, JL., MAIER,
B., and MIRMIRA, RG. Islet $\beta$-cell endoplasmic reticulum stress precedes the onset of type 1 diabetes in the nonobese diabetic mouse model. Diabetes, 2012, vol. 61, n. 4, p. 818-827. PMid:22442300 PMCid:PMC3314371. http://dx.doi.org/10.2337/dbl1-1293

WORLD HEALTH ORGANIZATION - WHO. Global status report on non-communicable diseases 2010. Geneva, 2011.

Received: May 24, 2014 Accepted: August 07, 2014 